\title{
Mycomyzostoma calcidicola gen. et sp. nov., the First Extant Parasitic Myzostome Infesting Crinoid Stalks, with a Nomenclatural Appendix by M. J. Grygier
}

\author{
Igor Eeckhaut \\ Laboratoire de Biologie marine, Université de Mons-Hainaut, \\ 19 Avenue Maistriau, 7000 Mons
}

(Reccived 10 March 1997; Accepted 24 Octobcr 1997)

\begin{abstract}
A new genus and species of Myzostomida is described by means of light and electron microscopy. Mycomyzostoma calcidicola is a parasitic myzostome inducing cysts on the stalks of Saracrinus nobilis, a crinoid collected around New Caledonia. The main characteristics of the species are the unusual body shape of the female, the total regression of the female parapodia, the absence of digestive caeca in the females, the total regression of the digestive system in the males, and the site of the cysts. The discovery of $M$. calcidicola re-opens the debate about the probable myzostomidan origin of parasitic traces occurring on prePennsylvanian crinoid stalks.

Key Words: Mycomyzostoma calcidicola gen. et sp. nov., cysticolous, crinoid, Saracrinus nobilis, trace fossil interpretation, stereom, ossicles, marine parasitology.
\end{abstract}

\section{Introduction}

Myzostomes are marine worms living in association with echinoderms, especially crinoids but also ophiuroids and asteroids. Their exact phylogenetic affinities are still unsettled, due mainly to their unique morphology: they are dorso-ventrally flattened, pseudo-segmented, acoelomate worms that have some annelidan characters (e.g., the possession of chaetae and trochophora larvae) as well as their own unique features (e.g., the presence of a myoepidermis and of spermatocysts in which spermatozoa differentiate) (Eeckhaut 1995).

The last significant taxonomic paper dealing with the higher classification of the Myzostomida was by Jägersten (1940), who divided the group into two orders and seven monogeneric families. Only two families, the Myzostomatidae and the Endomyzostomatidae (a senior synonym of Cystimyzostomatidae; see the nomenclatural appendix herein), include parasitic myzostomes that induce galls or cysts on crinoids (Jägersten 1940; Jangoux 1990). Gallicolous spccies reside in the tissues of crinoid arms or pinnules where they induce conspicious deformations of the original host ossicles, which considerably enlarge to finally surround the myzostomes (Graff 1884; Jangoux, 1990). Cysticolous species live in the tissues of crinoids where they do not (or not significantly) deform the original skeleton but often induce the formation of minute skeletal ossicles reinforcing the walls of their shelters.

Many deformities occurring on fossil crinoids have been attributed to myzostomes (Graff 1885; Warn 1974; Meyer and Ausich 1983), and the genus 
Myzostomites Clarke, 1921 has been proposed for some of them. Franzén (1974) pointed out that extant myzostomes always produce deformities on the pinnules, arms, or caly $x$ of crinoids and refuted the hypothesis of myzostomes being the agents responsible for deformities of fossil crinoid stalks. Several authors (Welch 1976; Meyer and Ausich 1983) have therefore recognized only some deformities (those on the arms, pinnules, or caly $x$ of fossil crinoids) as traces left by the parasitic activity of fossil myzostomes. All the cases admitted by Meyer and Ausich (1983) are Pennsylvanian or later.

The present paper describes the first extant parasitic myzostome, Mycomyzosloma calcidicola gen. et sp. nov., that infests crinoid stalks. Its host is the metacrinine Saracrinus nobilis (P. II. Carpenter, 1882). The myzostome and the deformities it induces have been studied by means of light and electron microscopy.

\section{Material and Methods}

Mycomyzostoma calcidicola and its crinoid host, Saracrinus nobilis, were collected by dredging in the West Pacific around New Caledonia during the French expeditions MUSORSTOM IV (30.09.1985; stn. 0222; $22^{\circ} 57.6^{\prime} \mathrm{S} 167^{\circ} 33.0^{\prime} \mathrm{E} ; 410-440 \mathrm{~m}$ depth) and BIOCAL (30.08.1985; stn. DW 38; $\left.22^{\circ} 59.74-94^{\prime} \mathrm{S} 167^{\circ} 15.31-42^{\prime} \mathrm{E} ; 360 \mathrm{~m}\right)$. The material was either directly preserved in $70 \%$ ethanol or fixed in Bouin's fluid beforehand.

For histological observations, individuals fixed in Bouin's fluid were dehydrated, embedded in Paraplast, cut into $5 \mu \mathrm{m}$ thick sections with an HM 340E Microm microtome, and stained with Masson's trichrome according to the procedure of Gabe (1968).

For SEM observations, myzostomes were dehydrated in graded concentrations of ethanol and dried by the critical point method using $\mathrm{CO}_{2}$ as the transition fluid. Crinoid's ossicles were digested in weak bleach beforehand. Samples were mounted on aluminium stubs, coated with gold in a sputter coater, and observed with a JEOL JSM 6100 scanning electron microscope.

Descriptions of the parapodial hook apparatus were based on an individual, the soft tissucs of which were digested in weak bleach. Once most of the tissues were dissolved, the hooks and support rods were dried and mounted on slides. Microscopic observations were made with an Olympus IMT-2 phase contrast microscope.

The type lot was deposited in the collection of the Muséum National d'Histoire Naturelle in Paris.

\section{Results}

Mycomyzostoma Eeckhaut, gen. nov.

Diagnosis. Dioecious species. Female body large, mushroom-shaped, with a large, spherical trunk, and a small, cylindrical introvert. Parapodia, hooks, support rods, cirri, buccal papilla absent. Digestive system with pharynx located in introvert and stomacho-intestinal pouch located in trunk. No digestive caeca. Ventral nerve cord condensed. One diffuse, marginal, asacular ovary. Oviduct a network of ducts 
merging into single main duct. One ano-genital pore. Male body small, leaf-shaped, with dorso-ventrally flattened trunk and no introvert. No lateral organs. No cirri. Five pairs of hooks with support rods. No digestive system. Ventral nervous chain made up of two coalescent tracts with five pairs of lateral nerve processes. One diffuse, marginal testicle composed of cyst cells. Peripheral efferent ducts merging into two parasagittal main efferent ducts. No seminal vesicles. No penes.

Type species. Mycomyzostoma calcidicola, gen. et sp. nov., by monotypy.

Mycomyzostoma calcidicola, gen. et sp. nov.

Material examined. A pair of myzostomes (one male and one female) collected during MUSORSTOM IV expedition at station 0222, 30.09.1985, designed here as the holotype (female; reference number: VE 730) and allotype (male; VE 731) and identified by M. J. Grygier in November, 1990, as a new species (and probably new genus) of Myzostomida. Two entire $S$. nobilis individuals and seven stalk segments of this crinoid, each bearing one cyst with myzostomes (Table 1). Paratypes (VE 732) consisting of five specimens (four females and one male) prepared for SEM, two specimens (one male and one female) sectioned for histological observations, one specimen (male) dissolved in bleach for parapodial hook apparatus observations, and two cysts left intact. Two myzostomes retained at the Université de Mons-Hainaut for further studies.

Etymology. The generic name is a combination of the Greek "myco", mushroom, referring to the unusual body shape, and "Myzostoma", a genus of Myzostomida. The

Table 1. Characteristics of the cysts induced on Saracrinus nobilis by Mycomyzostoma calcidicola gen. et sp. nov. collected around New Caledonia.

\begin{tabular}{|c|c|c|c|c|c|}
\hline $\begin{array}{c}\text { Cyst } \\
\text { number }\end{array}$ & $\begin{array}{l}\text { Length }^{b} \\
(\mathrm{~mm})\end{array}$ & $\begin{array}{c}\text { Diameter } \\
(\mathrm{mm})\end{array}$ & $\begin{array}{c}\text { Fixation/ } \\
\text { Conservation }\end{array}$ & Preparation & $\begin{array}{l}\text { Myzostomes } \\
\text { included }\end{array}$ \\
\hline 1 & 6 & 6 & $70 \%$ ethanol & dissected & $\begin{array}{l}1 \text { female prepared } \\
\text { for SEM }\end{array}$ \\
\hline 2 & 6 & 4.5 & $70 \%$ ethanol & dissected & $\begin{array}{l}1 \text { female prepared } \\
\text { for SEM }\end{array}$ \\
\hline 3 & 4.5 & 4.5 & $70 \%$ ethanol & $\begin{array}{l}\text { left entire in } \\
70 \% \text { ethanol }\end{array}$ & - \\
\hline 4 & 5.3 & 4.5 & $70 \%$ ethanol & dissected & $\begin{array}{l}1 \text { female left in } \\
70 \% \text { ethanol }\end{array}$ \\
\hline 5 & 12 & 9 & $70 \%$ ethanol & $\begin{array}{l}\text { left entire in } \\
70 \% \text { ethanol }\end{array}$ & $\ldots$ \\
\hline 6 & 9 & 9 & $70 \%$ ethanol & dissected & $\begin{array}{c}1 \text { female left in } \\
70 \% \text { ethanol }\end{array}$ \\
\hline 7 & 6 & 6 & $\begin{array}{l}\text { Bouin's fluid/ } \\
70 \% \text { ethanol }\end{array}$ & dissected & $\begin{array}{l}1 \text { female prepared for } \\
\text { SEM and } 1 \text { male } \\
\text { digested in bleach }\end{array}$ \\
\hline 8 & 6 & 6 & $\begin{array}{l}\text { Bouin's fluid/ } \\
70 \% \text { ethanol }\end{array}$ & dissected & $\begin{array}{l}1 \text { pair prepared for } \\
\text { SEM }\end{array}$ \\
\hline 9 & 6 & 6 & $\begin{array}{l}\text { Bouin's fluid/ } \\
70 \% \text { ethanol }\end{array}$ & dissected & $\begin{array}{l}1 \text { pair prepared for } \\
\text { histology }\end{array}$ \\
\hline
\end{tabular}

${ }^{\text {aC }}$ yst number 3 from BIOCAL; all the others from MUSORSTOM IV

'Length of the cyst axis perpendicular to the crinoid stalk axis 


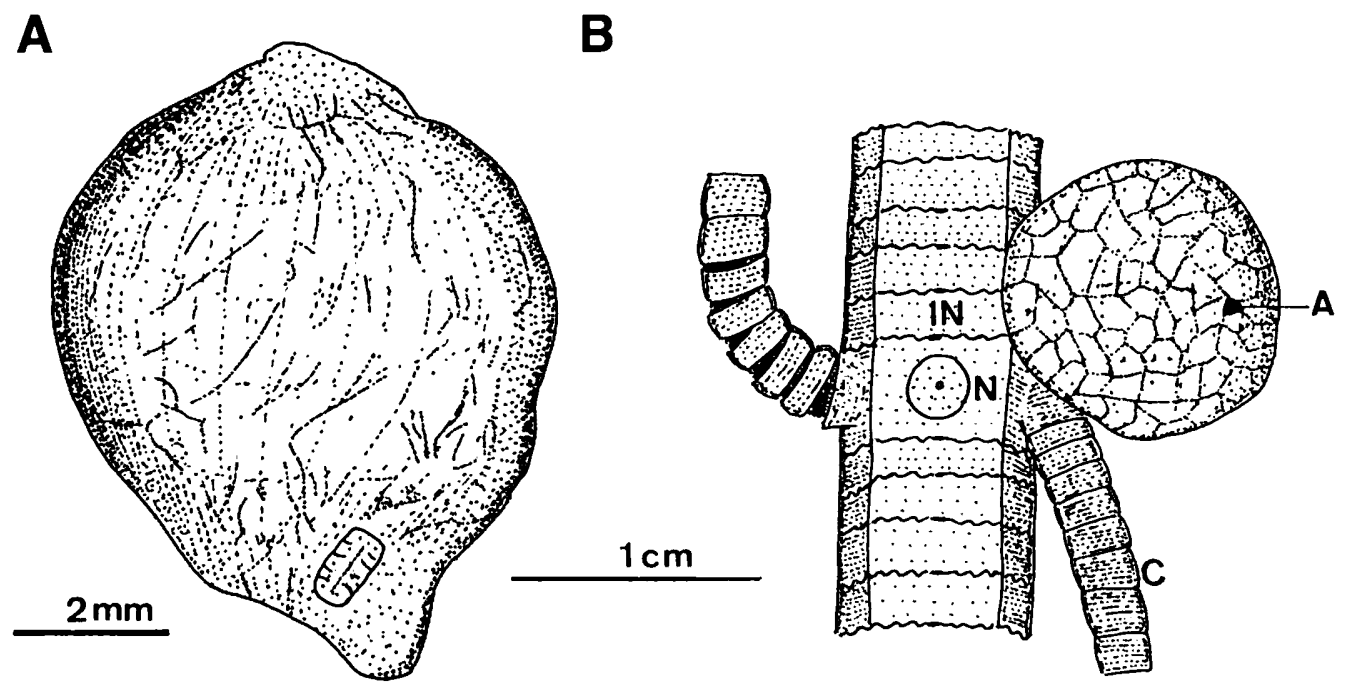

Fig. 1. Mycomyzostoma calcidicola gen. et sp. nov. Drawings of the holotype (female) bearing the allotype (male) on its trunk (A) and a cyst observed on the stalk of Saracrinus nobilis induced by these myzostomes (B). Abbreviations: A: cyst aperture; C: cirrus; IN: internodal; N: nodal.

specific name is a combination of the Latin "calcis", stalk, and "incola", inhabitant, referring to the site of cyst development.

Diagnosis. See generic diagnosis.

Description of the myzostomes. The female (holotype) is mushroom-shaped with a small, anterior, everted introvert of $0.5 \mathrm{~mm}$ in length and a large, posterior, spherical trunk of $7 \mathrm{~mm}$ in diameter (Fig. IA). The mouth appears as a small hole at the tip of the introvert; a small slit, the common pore for the digestive and female genital systems, opens opposite the mouth on a flat ano-genital plate. No lateral organs, cirri, or parapodia are observable. The whole body is coloured dirty white. Pleats of the stomacho-intestinal pouch are observed through the translucent trunk, cxcept at the level of the ano-genital plate, as a light network of lines surrounding darker areas. The leaf-shaped male (allotype) is attached by its ventral side to the female trunk near the introvert (Fig. 1A). It has no introvert but a trunk measuring $0.9 \mathrm{~mm}$ long, $0.6 \mathrm{~mm}$ wide, and ca $0.3 \mathrm{~mm}$ thick. Four pairs of $100 \mu \mathrm{m}$ deep marginal constrictions partially divide the trunk in five parts. There are no marginal cirri. The colour is uniformly white.

Out of the four females (paratypes) extracted from cysts fixed and preserved in $70 \%$ ethanol, two are hemispherical and measure 2.7 and $3.2 \mathrm{~mm}$ in diameter (cysts 4 and 6; Table 1), and the other two are mushroom-shaped, both of them $4 \mathrm{~mm}$ long (cysts 1,2; Table 1). The introverts of the first two are probably retracted. The last two females were prepared for SEM, but no appendages nor external organs were observed due to the bad fixation of the material.

The females of cysts 7 and 8 and one of the two males found were prepared for SEM. One female is hemispherical, $4.8 \mathrm{~mm}$ in diameter; the other is mushroom-shaped, $3 \mathrm{~mm}$ in diameter (Fig. 4). Both have the trunk integument glabrous and very pleated 
except at the level of the ano-genital plate, where it is smooth. The male is attached by its ventral side to the left side of the female trunk. It is leaf-shaped, $800 \mu \mathrm{m}$ long, $500 \mu \mathrm{m}$ wide, and ca $250 \mu \mathrm{m}$ thick (Fig. 5). Its surface is covered with tufts of 10 $\mu \mathrm{m}$ long cilia.

The male from cyst 7 was dissolved in bleach. It measured $800 \mu \mathrm{m}$ long, $500 \mu \mathrm{m}$ wide. Ten hooks of $50 \mu \mathrm{m}$ in length with their 10 accompanying support rods of 70 $\mu \mathrm{m}$ in length were revealed. The hooks and their support rods are arranged in five pairs along the antero-posterior axis of the myzostomes (Fig. 2D). Each hook is located halfway between the body margin and the myzostome's sagittal plane (Fig. 2D). There are no true parapodia but the hooks extrude from single ventral pores. The hooks are straight, basally dilated rods (Fig. 2C). The tip of each hook is flat and uncurved (but the ends of the hooks might be broken) (Fig. 2C). The support rod is slightly curved (Fig. 2C). Observed with the phase contrast microscope, it appears to have three darker areas (Fig. 2C). The base is wider than that of the hook and it tapers distally (Fig. 2C). The manubrium is a very small flag (Fig. 2C). No replacement hooks were observed.

The sectioned female from cyst 9 has an everted introvert and measured $3 \mathrm{~mm}$ in diameter (Figs $2 \mathrm{~A}, 2 \mathrm{~B}, 6$ ). Its digestive system consists of a pharynx located in the introvert and a stomacho-intestinal pouch, the end of which merges with the oviduct (Figs 2A, 2B). A mouth is present at the tip of the introvert. The common pore of the digestive and female genital systems opens on the ano-genital plate (Fig. 2A). There are no salivary gland cells nor digestive caeca. The digestive organs are made up of an epithelium surrounded by muscles, the latter being well developed around the pharynx and very thin around the stomacho-intestinal pouch (Fig. 2A). The pharyngeal epithelium is flat and borders a uniform, cylindrical lumen. The stomacho-intestinal pouch is pleated (the pleats might be due to the fixation), made up of a wide, spherical lumen and a number of pinched-off cylindrical lumina around the periphery (Figs 2A, 2B, 6). The stomacho-intestinal epithelium consists of club-shaped cells full of empty vacuoles that probably were filled with lipids before fixation (Figs 2A, 2B, 6). A small ventral nerve cord lies at the junction between the pharynx and the stomacho-intestinal pouch. No peripheral nerves nor peripharyngeal collar have been observed. The female genital system consists of a diffuse ovary and an oviduct (Figs 2A, 2B, 6). The ovary is asacular and lies in the trunk: the gametes develop in the parenchyma between the epidermis and the oviducal ducts (Figs 2A, 2B, 6). The gametes observed were oogonia and previtellogenic and vitellogenic oocytes. The oviduct consists of a network of ducts located between the pleats of the digestive system and converging to the ano-genital pore. The lumen of each duct is limited by a flat, ciliated epithelium. Inside the lumen lie oocytes (that came from the ovary by breaking through the thin oviducal epithelium) and spermatozoa (that came from the male individual). Sheets of spermatic syncytia (i.e., multinucleated cells whose internal cavities are filled with spcrmatozoa; see Eeckhaut and Jangoux (1991) for a detailed description of the myzostome reproductive process) were observed in the parenchyma close to the developing female gametes, which suggests that the reproductive process of $M$. calcidicola begins by the intradermic penetration of male sperm cells through the female integument. No excretory system was observed.

The sectioned male from cyst 9 was $800 \mu \mathrm{m}$ long and $500 \mu \mathrm{m}$ wide (Figs 2D, 2E, 7). It has no digestive system but a loose parenchyma. The well developed double 

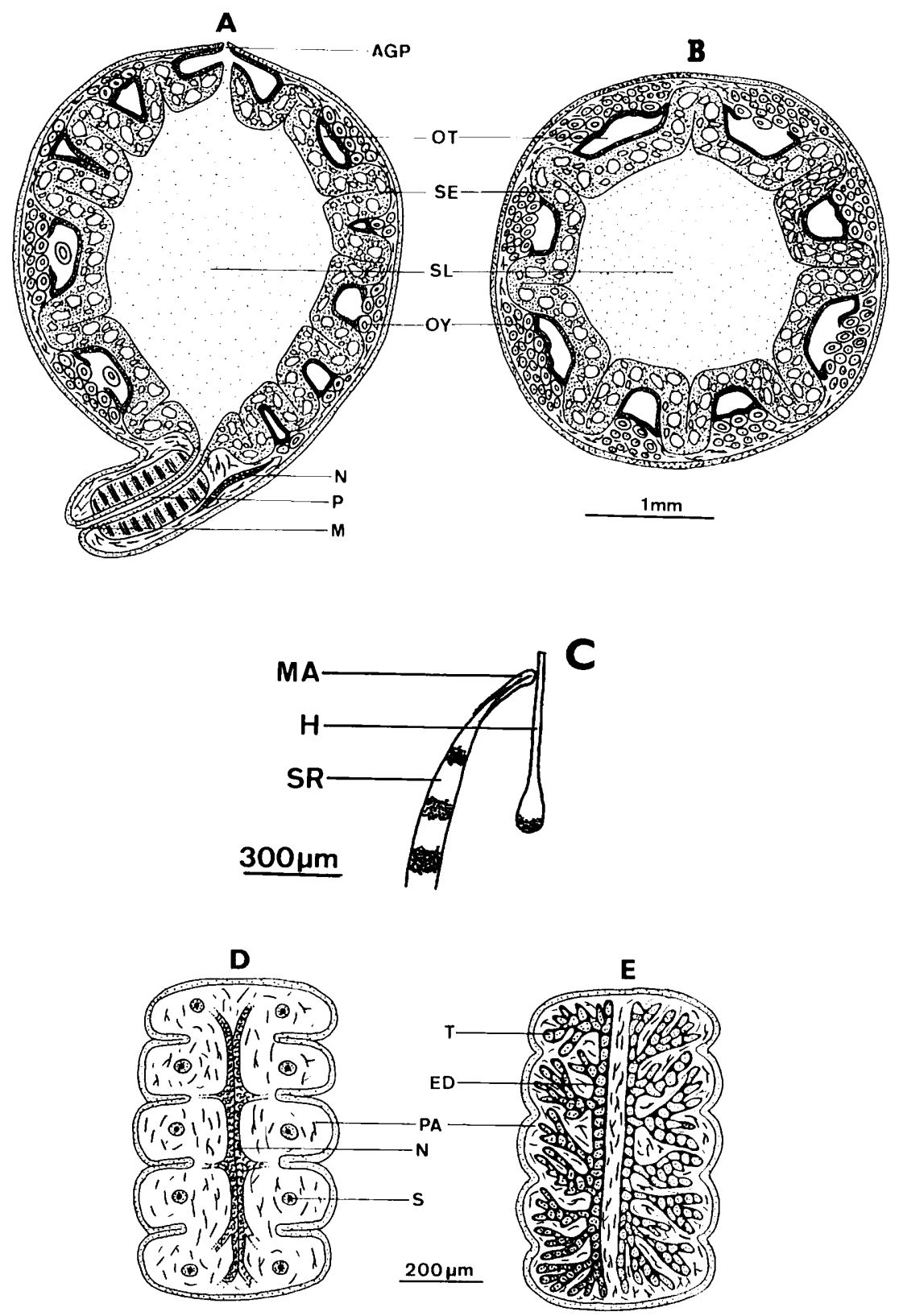

Fig. 2. Mycomyzostoma calcidicola gen. et sp. nov. Schematic drawings of sagittal (A) and mid-transversal (B) sections through a female, of the parapodial hook apparatus of a male (C), and of two frontal sections through the ventral (D) and dorsal (E) parts of a male. Abbreviations: AGP: ano-genital pore; ED: efferent duct; H: hook; M: mouth; MA: manubrium; N: ventral nerve chain; OT: oviduct; OY: ovary; P: pharynx; PA: parenchyma; S: site of a hook; SE: stomacho-intestinal epithelium; SL: stomacho-intestinal lumen; SR: support rod; T: testicle. 


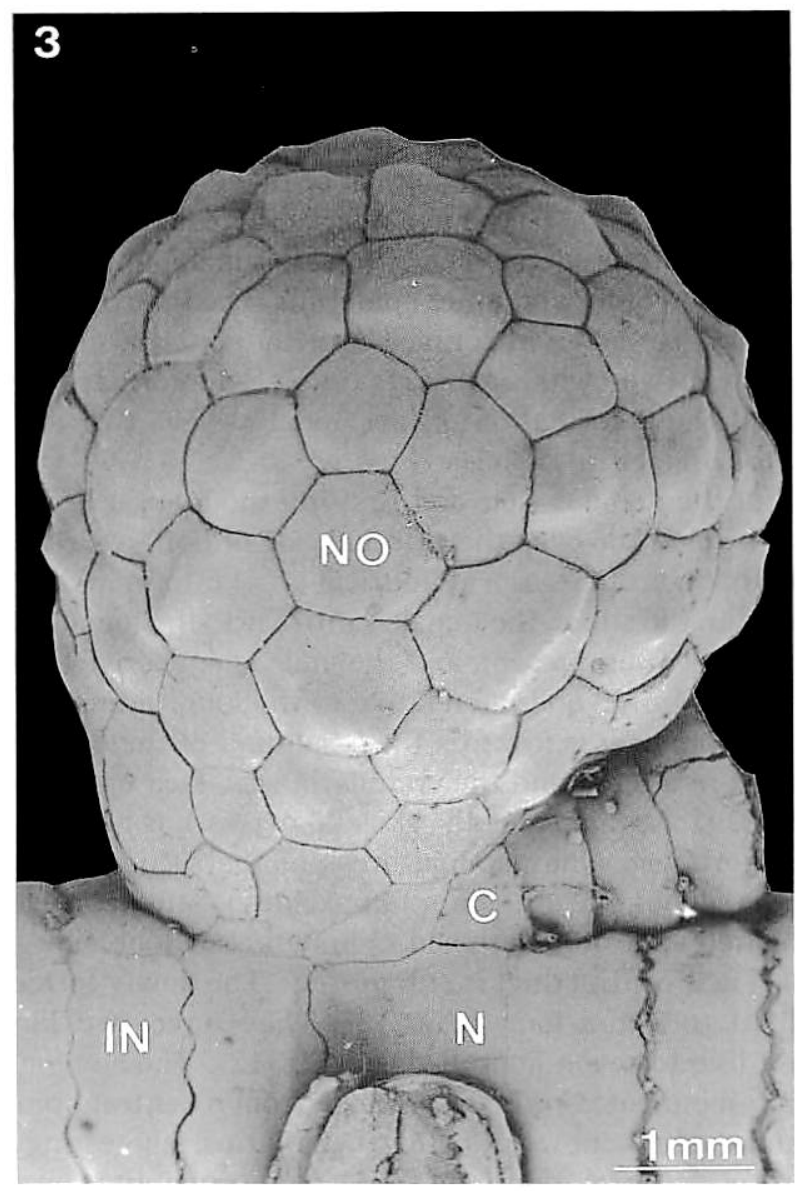

Fig. 3. Cyst induced by Mycomyzostoma calcidicola gen. et sp. nov. on the stalk of the crinoid Saracrinus nobilis (SEM view). The longitudinal axis of the stalk is horizontal. Abbreviations: C: cirrus; IN: internodal; N: nodal; NO: new ossicle.

ventral nerve cord is made up of two coalescent tracts and gives rise to five pairs of lateral nerve processes that spread out into thin secondary nerve processes (Fig. 2D). The male genital system consists of a diffuse testicle and efferent ducts (Figs 2E, 7). The testicle is located in the periphery of the whole animal, just below the epidermis. It consists of numerous cyst cells, the internal cavity of which is filled with spermatozoa. All the cysts accumulate in two parasagittal main efferent ducts through a lot of peripheral efferent ducts (Figs 2E, 7). The efferent ducts have no epithelium but merely a basal lamina. There are no deferent ducts (i.e., well epithelialized ducts conducting the cysts to either the exterior or into a seminal vesicle), nor seminal vesicles (i.e., bilateral pouches in which cyst cells accumulate and form a spermatophore). Although it is not obvious in the sections, the two main efferent ducts probably open to the exterior by a pair of pores located close to the third pair of parapodia. No excretory system was observed. 
Description of the cysts. There is only one cyst on each infested crinoid. All the cysts are located in the middle part of the stalk and are in contact with the base of a cirrus (Figs 1B, 3). Two of the cysts were located above their cirri, forcing the latter to point downward (cirri of Saracrinus nobilis naturally point upward). All the others were below their cirri. The cysts are spherical or ovoid and measure 4.5 to $9 \mathrm{~mm}$ in diameter (Table 1; Figs 1B, 3). They have a large internal cavity, inside of which a female or a pair of myzostomes lives. The cyst wall is made up of host tissue: a dermis including ossicles and an outer and inner epidermis. The internal cavity can be either totally closed (in most cases) or in contact with the external medium through one small, circular pore (in two cysts). All cysts involve the formation of 70 to 90 new minute ossicles and the deformation of one nodal ossicle, two to three internodal ossicles, and one to three cirral ossicles (Figs 1B, 3).

The skeleton of the nodal ossicle and first internodal ossicle is strongly altered (Figs 8, 9). At the level of the cyst, the external side of both ossicles is penetrated by a deep depression that continues as a cylindrical pit of $50 \mu \mathrm{m}$ in diameter (Figs 8, 9). The pit corresponds to the site of the female's introvert (the female's ano-genital pore faces the cyst aperture when present, and the male is squeezed between the female and the cyst wall). The pit is oblique relative to the longitudinal axis of the crinoid stalk, and directed more or less towards the axial duct of the columnals (Figs 8, 9). Two petaloid areas are altered and the crenularia that face each other have totally disappcared (Figs 8,9). At that level, the skeletal network is not regular but includes unusual holes and grooves. The petaloid areas of the second and third internodal ossicles are not altered, but one of their external sides is still depressed (Fig. 10). The deformed cirral articles are not flattened cylinders, but look like parts of broken spheres (Fig. 11). Their central duct is still present. The newly formed ossicles of the cyst are generally 1 to $2 \mathrm{~mm}$ long (Fig. 12). They have two large internal and external faces and five to seven lateral edges (Fig. 12). The stereom of the internal side consists of interconnected rods that radiate from a central point (Fig. 13). The stereom of the lateral edges shows growing skeletal tips, suggesting that the ossicles are still in the process of formation (the whole cyst probably grows in concert with the myzostomes) (Fig. 14). The stereom of the external face is made up of the usual regular network of rods (Fig. 15).

\section{Discussion}

The exact phylogenetic position of the myzostomes and their rank in the Linnean hierarchy are unsettled. Recently the Myzostomida have been considered as bcing a monophyletic taxon outside the Annelida (Salvini-Plawen 1982; Haszprunar 1996) or as a family of polychaetes close to the phyllodocids (Rouse and Fauchald 1995). This uncertainty obviously bears on the taxonomic rank that should be accorded to the present new species. The myzostomes probably are a sister group of the polychaetes because all the characters they share with them are plesiomorphic ones found in other phyla (e.g. presence of a trochophora larva, presence of hooks). Yet they have at least one apomorphic character not shared by any (other) annelids, the presence of cyst cells. Mycomyzostoma calcidicola is considered here as a new genus of the family Endomyzostomatidae, a senior synonym introduced by Perrier (1897) of the family Cystimyzostomatidae (see appendix hereafter). The 
Endomyzostomatidae include two genera, Endomyzostoma (=Cystimyzostomum) and Contramyzostoma (though the familial assignment of the latter taxon is put in doubt by Grygier (in press)). Mycomyzostoma calcidicola shares the following characters with the Endomyzostomatidae: (1) they are cysticolous parasites, (2) they are dioecious (a condition only occurring in a few endomyzostomatids; most of them being protandrous hermaphrodites), and (3) cirri and lateral organs are absent (they are absent or reduced in endomyzostomatids). The new species differs from all endomyzostomatids but also from all other myzostomes by (1) the shape of the females, (2) the total regression of the female parapodia, (3) the absence of digestive caeca in the females, (4) the total regression of the digestive system in the males, and (5) the site of cyst development on crinoid stalks.

The only species of the genus Stelechopus, S. hyocrini Graff, 1884, is also found on stalked crinoids. That species, like the male of $M$. calcidicola, is leaf-shaped, has reduced parapodia, no cirri, and no introvert, but it has two pairs of lateral organs and it is hermaphrodite.

The fact that $M$. calcidicola induces cysts on crinoid stalks re-opens the debate about the origin of parasitic traces occurring on fossil crinoid stalks. Before 1976, any boreholes with associated swellings on fossil crinoids were most commonly assigned to the parasitic activities of myzostomes (Graff 1885; Warn 1974). The studies of Welsh (1976), Brett (1978), and Meyer and Ausich (1983) restricted the myzostome infestations on fossil crinoids to spherical or ellipsoidal swellings on the arms and calyx with usually a single noncircular opening to the exterior. With this restricted definition of myzostome infestations, relations between crinoids and myzostomes are first recognized during the Pennsylvanian (Meyer and Ausich 1983). The main argument against the hypothesis of a myzostomidan origin for deformities occurring on fossil crinoid stalks (i.e., the fact that no extant myzostomes parasitize crinoid stalks) is refuted by the existence of $M$. calcidicola. However, the cysts induced by $M$. calcidicola are not fully similar to fossil deformities. The latter are either depressions on columnals or spherical to ellipsoid galls in columnals with single or double circular openings leading into an internal cavity (Brett 1978; Meyer and Ausich 1983). The cysts of $M$. calcidicola are similar to fossil galls in that they include deformed columnals but differ by the presence of many new, minute ossicles. However, once the new ossicles induced by $M$. calcidicola are removed from the cysts, the deformities of the columnals of Saracrinus nobilis are very similar to some fossil deformities. One can suggest that the small ossicles may naturally be lost after the crinoid death or during fossilization. Furthermore, the discovery of the cysticolous $M$. calcidicola suggests that gallicolous myzostomes as well may have infested crinoid stalks during the past. Fossil deformities dating back before the Pennsylvanian, like those assigned to the genus Phosphannulus (see Welsch 1976), should be carefully re-checked, taking into account the probable existence of such myzostomes.

\section{Aknowledgements}

I thank Dr. Nadia Améziane for having determined the crinoid hosts and Dr. Alain Crosnier for sending me the biological material, both belonging to the Muséum National d'Histoire Naturelle, Paris. I also thank Dr. Mark J. Grygier for 

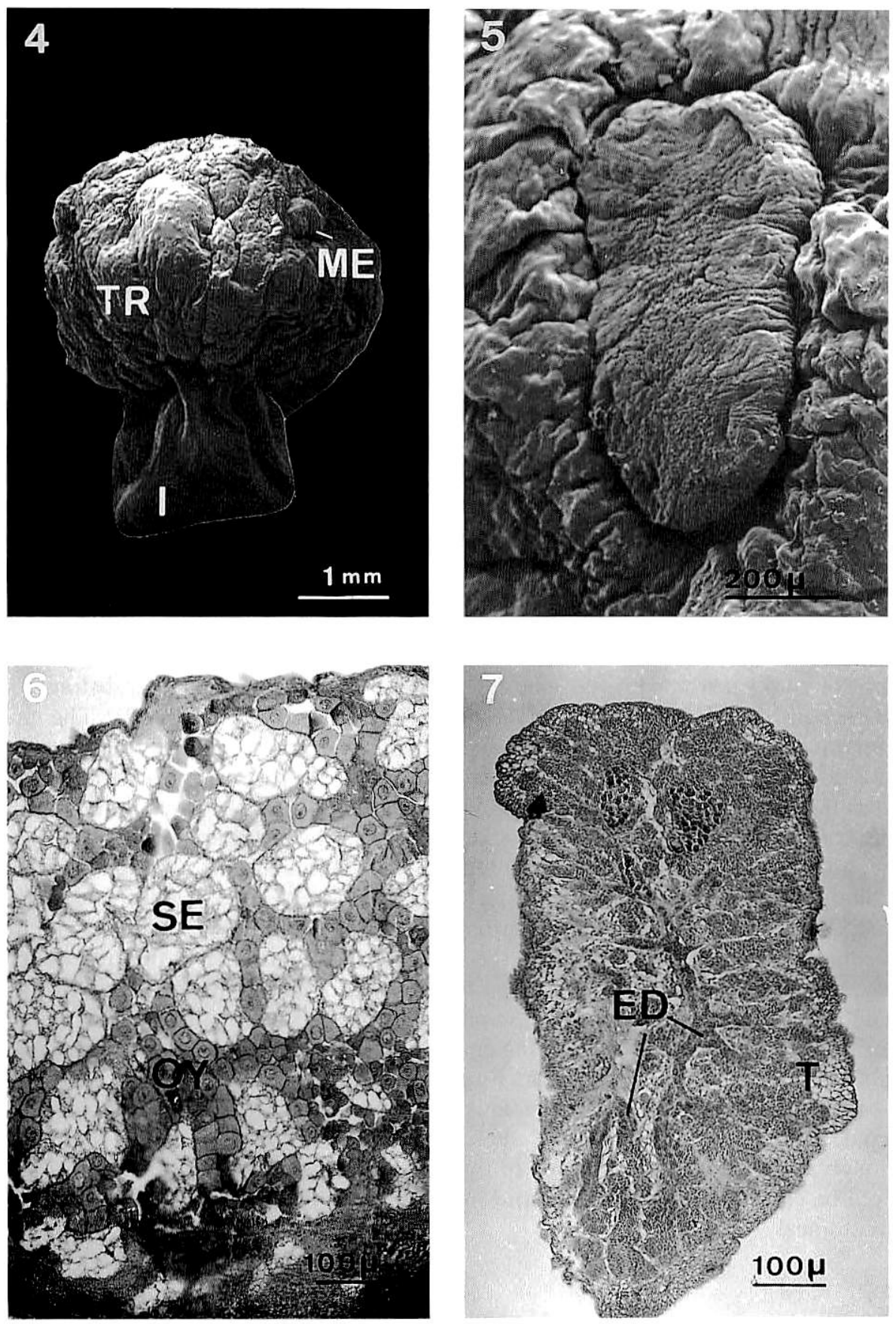

Figs 4 to 7. Mycomyzostoma calcidicola gen. et sp. nov. SEM views of a pair of myzostomes extracted from a cyst (4) and of the male which is attached to the female's trunk (5); longitudinal section through the margin of a female trunk showing the disposition of the ovary and of the 

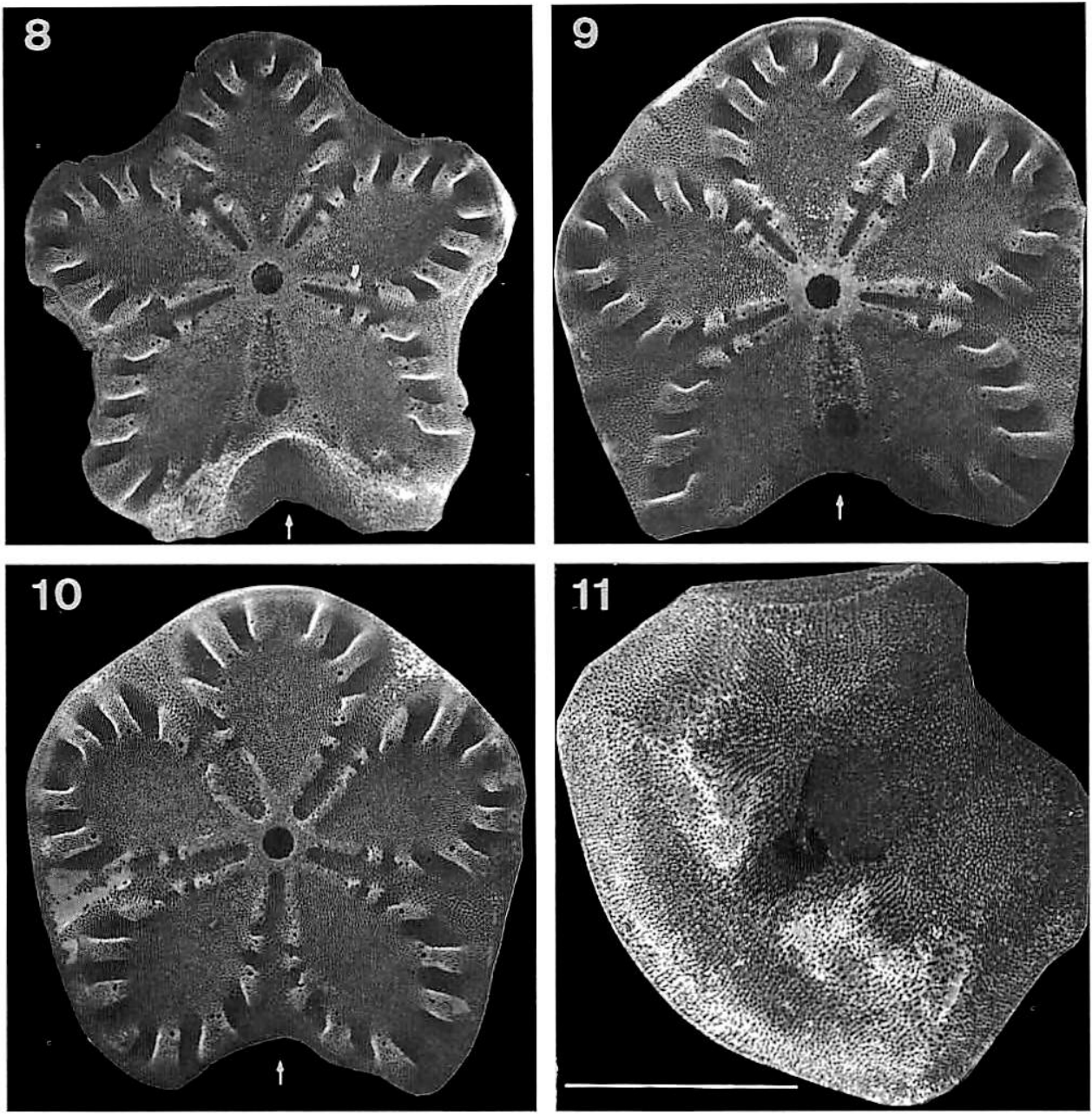

Figs 8 to 11. Mycomyzostoma calcidicola gen. et sp. nov. SEM views of the nodal (8), 1st internodal (9), 2nd internodal (10), and 1st cirral ossicle (11), all deformed by the presence of the myzostomes. Arrows show the deformed part of the columnals. Scale bar $=0.5 \mathrm{~cm}$ in Figs 8 , 9, 10 and $1 \mathrm{~mm}$ in Fig. 11.

recommending that Dr. Crosnier gives the myzostomes to me for study, and for his advice on composing the name of the new species. Thanks are also expressed to Paul Postiau for his technical assistance. I. Eeckhaut is a Senior Research Assistant of the Belgian National Fund for Scientific Research. This is a contribution of the Centre Interuniversitaire de Biologie Marine (CIBIM).

stomacho-intestinal pleats (6); frontal section through the dorsal part of the male body (7). Abbreviations: ED: efferent duct; I: introvert; ME: male; OY: ovary; SE: stomacho-intestinal epithelium; T: testicle; TR: trunk. 

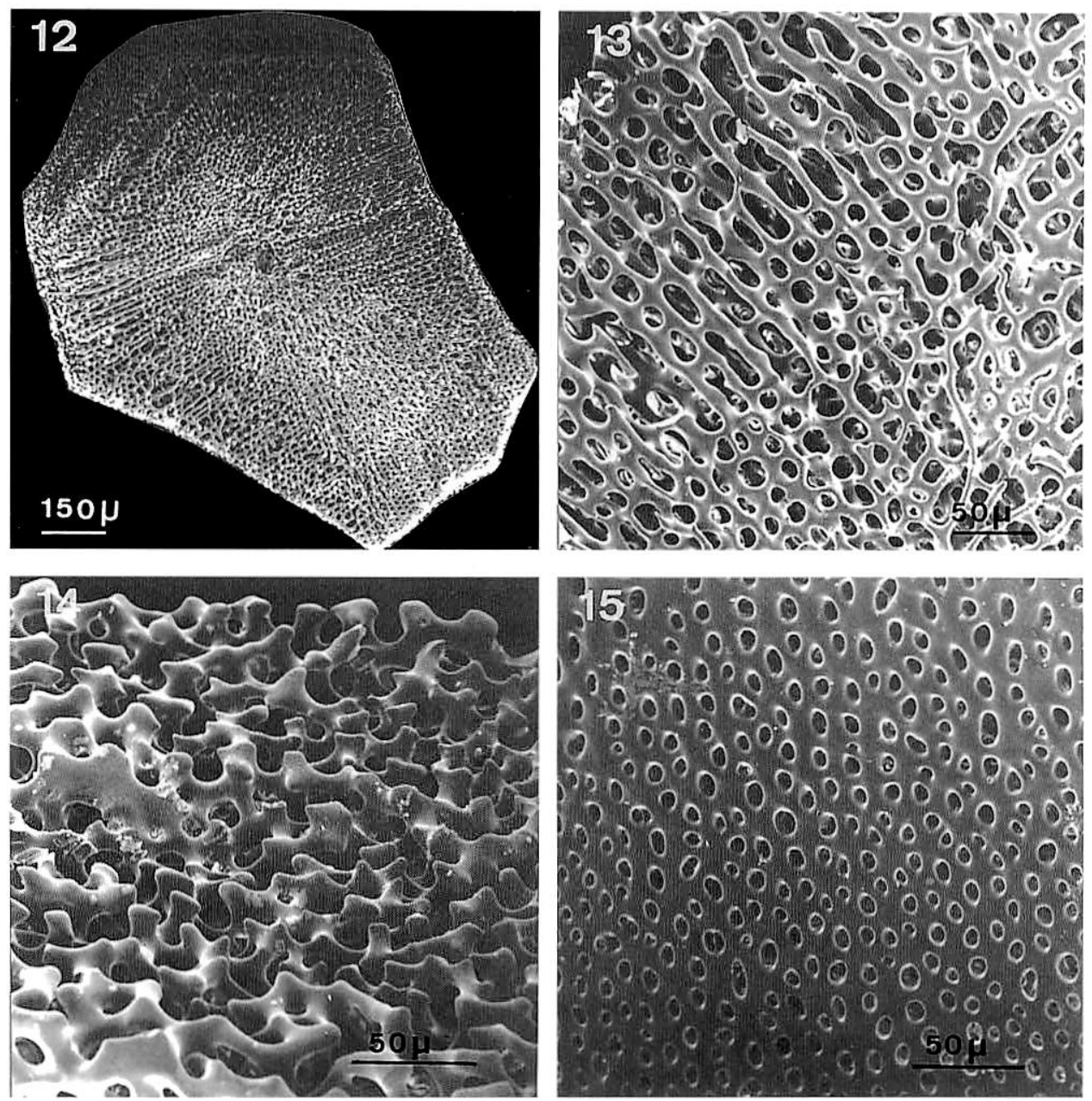

Figs 12 to 15. Mycomyzostoma calcidicola gen. et sp. nov. SEM views of the inner face of a new ossicle included in the cyst wall (12) and details of the stereom of the inner face (13), lateral edge (14), and outer face (15) of the cyst ossicles.

\section{References}

Brett, C. E. 1978. Host-specific pit-forming epizoans on Silurian crinoids. Lethaia 11: 217-232. Eeckhaut, I. and M. Jangoux 1991. Fine structure of the spermatophore and intradermic penetration of sperm cells in Myzostoma cirriferum (Annelida, Myzostomida). Zoomorphology 111: 49-58.

Eeckhaut, I. 1995. Cycle vital et biologie de Myzostoma cirriferum (Myzostomida), symbiote obligatoire de la comatule Antedon bifida (Echinodermata). PHD thesis, University of Mons-Hainaut, 106 pp.

Franzèn, C. 1974. Crinoid holdfasts from the Silurian of Gotland. Lethaia 10: 219-234.

Gabe, M. 1968. Techniques Histologiques. Masson, Paris. 
Graff, L. von 1884. Report on the Myzostomida collected during the voyage of H.M.S. Challenger during the years 1873-76. Report on the Scientific Results of the Voyage of H.M.S. Challenger, Zoology 10: 1-82, PIs. I-XVI.

Graff, L. von 1885. Ueber einige Deformitäten an fossilen Crinoiden. Palaeontographica 31: 185-191, plate XVI(I).

Grygier, M.J. in press. Myzostomida. The Fauna of Australia. Vol. 4. Annelida to Tunicata.

Haszprunar, G. 1996. The Mollusca: coelomate turbellarians or mesenchymate annelids? Pp. 3-28. In: Taylor, J.D. (Ed.) Origin and Evolutionary Radiation of the Mollusca. Oxford Science Publications, Oxford, New York, Tokyo.

Jägersten, G. 1940. Zur Kenntnis der Morphologie, Entwicklung und Taxonomie der Myzostomida. Nova Acta Regiae Societatis Scientiarum Upsaliensis (4) 11 (8): 1-84, Pls. I-VII.

Jangoux, M. 1990. Diseases of Echinodermata. Pp. 439-467. In: Kinne, O. (Ed.) Diseases of Marine Animals. Vol. 3. Biologische Anstalt Helgoland, Hamburg.

Meyer, D. L. and Ausich, W. I. 1983. Biotic interactions among recent and among fossil crinoids. Pp. 377-427. In: Tevesz, M.J.S. and McCall, P.L. (Eds) Biotic Interactions in Recent and Fossil Benthic Communities. Plenum Publishing Corporation, New York.

Perrier, E. 1897. Philocrinida. P. 1633. In: Perrier, E. (Ed.) Traité de Zoologie. Fascicule IV. Vers (Suite) - Mollusques - Tuniciers. Masson, Paris.

Rouse, G. W. and Fauchald, K. 1995. The articulation of annelids. Zoologica Scripta 24(4): 269-301.

Salvini-Plawen, L. von 1982. A paedomorphic origin of the oligomerous animals. Zoologica Scripta 11(2): 77-81.

Warn, J. M. 1974. Presumed myzostomid infestation of an Ordovician crinoid. Journal of Palcontology 48(3): 506-513, Pl. I.

Welsch, J. R. 1976. Phosphannulus on Paleozoic crinoid stems. Journal of Paleontology 50(2): $218-225$.

\section{Nomenclatural Appendix}

\section{Mark J. Grygier}

Tropical Biosphere Research Center (Sesoko Station), University of the Ryukyus Sesoko 3422, Motobu-cho, Okinawa 905-0227, Japan

(Current address: Lake Biwa Museum, Oroshimo 1091, Kusatsu, Shiga 525-0001, Japan)

It was necessary in the present work to compare the new species Mycomyzostoma calcidicola Eeckhaut with other cysticolous and gallicolous myzostomes. Most of these had been assigned by Jägersten (1940) to his new genus Cystimyzostomum in the family Cystimyzostomidae (corrected spelling: Cystimyzostomatidae). Jägersten originally included 10 nominal species in this genus but did not designate a type species. So far as I am aware, no later author has designated a type species either. Of the originally included species, Jägersten himself only studied Antarctic specimens of Myzostoma cysticolum Graff, 1883 sensu Stummer-Traunfels (1908) and Boulenger (1916). Therefore, I designate $M$. cysticolum as originally proposed by Graff (1883, 1884) as the type species of Cystimyzostomum, even though the Antarctic form is 
probably a distinct species from the Caribbean type lot (denied by StummerTraunfels 1908). Cystimyzostomum has continued in use until the present day and various authors have included different species in it (e.g., Jangoux 1990; Eeckhaut and Améziane-Cominardi 1994).

However, two available but long-unused senior synonyms of Cystimyzostomum exist. Perrier (1897) proposed several genera and two tribes within the family Myzostomidae (i.e., Myzostomatidae) of the polychaete order Philocrinida (his newly coined name for Myzostomida). The tribe Endomyzostominae (corrected spelling: Endomyzostomatinae) was defined by a lack of suckers (i.e., lateral organs) and the habit of deforming the pinnules to which they are attached, thereby producing a kind of chamber that they inhabit. The two genera recognized within this tribe were Endomyzostoma (Perrier's definition: hermaphrodites) and Heteromyzostoma (Perrier's definition: sexes separate with dwarf males); a single species was explicitely assigned to each, E. pentacrini (Graff, 1884) and H. tenuispinum (Graff, 1884), respectively, and these are therefore the type species by monotypy. These are both among the species originally included by Jägersten (1940) in Cystimyzostomum, which is therefore a subjective junior synonym of both of Perrier's genera. Furthermore, the tribe Endomyzostomatinae's coordinate family Endomyzostomatidae Perrier, 1897 is a senior subjective synonym of Cystimyzostomatidae. On the non-morphological and thus dubious grounds that they induce galls rather than cysts, strictly speaking, Jangoux (1990) transferred C. pentacrini and C. lenuispinum from Cystimyzostomum back to Myzostoma. If accepted, this act together with the type species designation above would remove the synonymy problem, but Grygier (in press) considers Jangoux's an artificial classification and Eeckhaut and Améziane-Cominardi (1994) continued to treat C. lenuispinum as Cystimyzoslomum. If the generic synonymy is recognized, then either Endomyzostoma or Heteromyzostoma must be used in place of Cystimyzostomum. Endomyzostoma has line priority in Perrier (1897).

Both type species were represented by abundant material and they and their galls were described equally well by Graff (1884). I only found specimens of $M$. tenuispinum in The Natural History Museum in London in 1986, and it is possible that the type lot of $M$. pentacrini has been lost. Nonetheless, because of the available family name Endomyzostomatidae, acting as first reviser I choose Endomyzostoma to have priority over Heteromyzostoma and to be used in place of Cystimyzostomum. Although this amounts to resurrecting a nomen oblitum that has evidently never been used or cited since its proposal, none of the names involved is of any wider significance in zoology, agriculture, fisheries, medicine, or parasitology. Therefore, strict adherence to the Principle of Priority seems to be appropriate.

\section{Additional References}

Boulenger, C. 1916. Myzostomida. British Antarctic ("Terra Nova") Expedition, 1910. Natural History Report. Zoology 2: 135-140, Pl.I.

Eeckhaut, I. and Améziane-Cominardi, N. 1994. Structural description of three myzostomes parasites of crinoids and of the skeletal deformities they induce on their hosts. Pp. 203-209. In: David, B., Guille, A., Feral, J.-P. and Roux, M. (Eds) Echinoderms through Time. Proceedings of the Eighth International Echinoderm Conference. Balkema, Rotterdam. 
Graff, L. von 1883. Verzeichniss der von der United States Coast Survey steamers "Hassler" und "Blake" von $1867 \mathrm{zu} 1879$ gesammelten Myzostomiden. Bulletin of The Museum of Comparative Zoology, at Harvard College 11: 125-133

Stummer-Traunfels, R.R. von 1908. Myzostomidae. National Antarctic Expedition Natural History 4: 1-26. 
